\title{
Pediatric Maxillofacial Trauma Management Experience at Tertiary Care Hospital - A Retrospective Study
}

\author{
Khurram Jah Zafar ${ }^{1}$ \\ Omer Sefvan Janjua ${ }^{2}$ \\ Maleeha Khurram $^{3}$ \\ Muhammad Usman Khalid ${ }^{4}$ \\ Muhammad Imran Saleh
}

Ayesha Moughal $^{6}$

\author{
BDS, FCPS, FFD RCS \\ BDS, FCPS, FFD RCS \\ BDS, M.Phil \\ BDS, FCPS \\ BDS, MDS \\ BDS
}

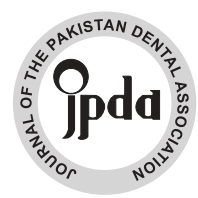

OBJECTIVE: To establish the etiology, pattern, management and outcome of maxillofacial trauma in pediatric patients. METHODOLOGY: A three-year record of pediatric patients who suffered from maxillofacial trauma was reviewed and analyzed using hospital database. The data gathered from the record of the patients like age was presented as mean and standard deviation whereas data like gender, etiology of particular trauma, anatomic position of fracture, affiliated injuries, kind of treatment used and outcome of the treatment was presented as frequency and percentage. Study Design: Retrospective study. Setting and Duration: Department of Oral \& Maxillofacial Surgery, Faisalabad Medical University, Faisalabad. January 2016 to January 2019.

RESULTS: Out of 135 pediatric maxillofacial trauma patients 91 (67.4\%) were males and 44 (32.6\%) were females making male to female ratio of 1.8:1. The mean age of the pediatric patients was $6.5+2.63$ years. Fall was the most common etiology $83(61.5 \%)$ of the trauma followed by RTA $40(29.6 \%)$. Out of 157 different fracture types $113(71.9 \%)$ occurred in mandible, and among mandible parasymphysis region was most commonly $42(37.1 \%)$ fractured site. Majority of the patients were treated by ORIF $80(59.3 \%)$. The concomitant injuries were observed in $31(22.9 \%)$ patients and among these neuro-cranial injuries were most common in $19(61.3 \%)$ patients. Post treatment complications were observed in $16(11.9 \%)$ patients and among these limited mouth opening was the most commonly seen complication $8(50 \%)$ patients.

CONCLUSION: The results of this study verified pediatric male patient's predominance. Mandible fracture was the most frequent site of pediatric maxillofacial trauma, predominantly caused by a fall. Majority of maxillofacial fractures were managed by open reduction and internal fixation. There is a need at a national level for a public, parent and teacher education program on child-care and safety.

KEY WORDS: Maxillofacial trauma, Pediatric, Management.

HOW TO CITE: Zafar KH, Janjua OS, Khurram M, Khalid MU, Saleh MI, Moughal A. Pediatric maxillofacial trauma management experience at tertiary care hospital - A retrospective study. J Pak Dent Assoc 2020;29(1):3-8.

DOI: https://doi.org/10.25301/JPDA.291.3

Received: 05 April 2019, Accepted: 30 October 2019

\section{INTRODUCTION}

I $\mathrm{n}$ children, trauma is the major source of morbidity and mortality, due to their pronounced cranial-mass to body ratio which is $8: 1$ at time of birth compared to $2.5: 1$

1. Senior Registrar, Department of Oral Maxillofacial Surgery, Faisalabad Medical University Allied Hospital Faisalabad.

2. Associate Professor, Department of Oral Maxillofacial Surgery, Faisalabad Medical University Allied Hospital Faisalabad.

3. Assistant Professor, Department of Science of Dental Materials, University Medical Dental College, Faisalabad, Pakistan.

4. Associate Professor, Department of Oral Maxillofacial Surgery, Faisalabad Medical University Allied Hospital Faisalabad.

5. Assistant Professor, Department of Oral Maxillofacial Surgery, de Montmorency College of Dentistry Punjab Dental Hospital Lahore.

6. Resident Trainee, Department of Oral Maxillofacial Surgery, Faisalabad Medical University Allied Hospital Faisalabad.

Corresponding author: "Dr. Khurrum Jan Zafar" < drkhurram1982@hotmail.com > in adulthood. ${ }^{1,2}$ The occurrence of maxillofacial trauma in pediatric population is not as common as compared to adults and fractures are also displaced minimally. ${ }^{3}$

The reason for the reduced incidence of maxillofacial trauma in pediatric patients when juxtaposed to adult patients is possibly due to the flexible bones of face, improper paranasal sinuses pneumatization and conservation of the malar area by buccal fat pad., $3,4,5$

Trauma involving the facial region is mainly notable due to observable placement of the face, its esthetic significance and psychological role harmfully influencing the leading uses like mastication, deglutition, speech and respiration. ${ }^{4,6}$

The manner of maxillofacial trauma in pediatric patients fluctuates between the different countries depending upon 
their environmental, cultural and socioeconomic factors. ${ }^{3,6}$ Road traffic accidents (RTA), fall, sports injuries and violence are the dominant causes of pediatric maxillofacial trauma. ${ }^{4,6,7}$

Injuries associated with pediatric maxillofacial trauma described in the literature differ extensively in the range of $10 \%$ to $75 \%$ relying on the particular type of fracture. ${ }^{1}$ According to one study conducted in China, it was noted that maxillofacial injuries in pediatric population was $23 \%$ and in adult population it was $77 \% .^{1,2,8}$ Whereas prevalence of pediatric maxillofacial trauma in Pakistan is around $34 \% .^{3,8}$

The recognition of maxillofacial trauma in pediatric population is quite demanding as sometimes the history is difficult to acquire or due to uncooperative nature of young trauma victim clinical examination may be impossible. ${ }^{2,8}$ Plain radiographs are tough to explain in children mainly in the region of mid face where imperfectly developed sinuses and presence of tooth buds employ area and vague the landmarks of anatomic structures and therefore computed tomography which provides diagnostic details is commonly utilized..$^{1,2}$

The management of pediatric maxillofacial trauma is based on the particular pattern and seriousness of the trauma, usually fractures which are minimally displaced can be managed by observation supplemented with a liquid, soft diet and medication whereas dislodged fractures frequently need closed or open treatment modalities. ${ }^{6.9}$ The objective of this current study was to determine the etiology, pattern, management and outcome of maxillofacial trauma in pediatric population so that proper preventive management policies can be developed on the basis of this published data.

\section{METHODOLOGY}

This was a retrospective study of pediatric patients with maxillofacial trauma who were managed in the department of Oral \& Maxillofacial Surgery Faisalabad Medical University, Faisalabad for a period of three years from January 2016 to January 2019. A predesigned template was developed and the patient record was reviewed and analyzed using the hospital database. The approval of the study and authorization to analyze the medical records of the trauma patients was obtained by the ethical committee of Faisalabad Medical University, Faisalabad.

The data gathered from the patient's previous information were; age, gender, etiology of trauma, particular site of fracture, concomitant injuries, type of treatment provided and outcome of the treatment. In order to eliminate the intraobserver error, the data assembling process was closely supervised by the same observer who reviewed and completed the data collection process.
Inclusion Criteria: Patient's age below 12 years and patients with complete records were included in the study.

Exclusion Criteria: Patient's age above 12 years, patients with incomplete records and those with only soft tissue injuries were excluded from the study.

\section{STATISTICAL ANALYSIS}

The composed data were entered and scrutinized using SPSS version 21.0 (SPSS Inc., Chicago, IL, USA). Quantitative variables like age were presented as mean and standard deviation. Qualitative data like gender, etiology of particular trauma, anatomic position of fracture, affiliated injuries, kind of treatment used and outcome of the treatment were presented as frequencies and percentages. ${ }^{1,6,8}$

\section{RESULTS}

The study population comprised of total 135 pediatric patients with maxillofacial trauma. There were 91 (67.4\%) were males and $44(32.6 \%)$ were females making male to female ratio of $1.8: 1$. The mean age of the patients was $6.5+2.63$ years with the minimum age of 2 years and maximum age of 11 years.

The most common etiology for the pediatric maxillofacial trauma in this study was due to fall with a very high frequency of $83(61.5 \%)$ followed by RTA 40 (29.6\%), sports injury $8(5.9 \%)$, Assault $2(1.5 \%)$, Gunshot injury $1(0.7 \%)$ and animal related injury $1(0.7 \%)$ (Table: 1$)$.

The frequency and site distribution of the pediatric fractures showed that out of 157 different fractures 113 (71.9\%) fractures occurred in mandible and 44 (28.1\%)

Table 1: Etiology of fractures in the present study

\begin{tabular}{|c|c|c|}
\hline Etiology & No. of patients & Percentage \\
\hline Fall & 83 & $61.5 \%$ \\
\hline $\begin{array}{c}\text { Road traffic } \\
\text { accident }\end{array}$ & 40 & $29.6 \%$ \\
\hline $\begin{array}{c}\text { Sports Injury } \\
\text { Assault }\end{array}$ & 8 & $5.9 \%$ \\
\hline Gunshot injury & 1 & $1.5 \%$ \\
\hline $\begin{array}{c}\text { Animal related } \\
\text { injury }\end{array}$ & 1 & $0.7 \%$ \\
\hline Total & 135 & $0.7 \%$ \\
\hline
\end{tabular}

fractures occurred in all other sites (Table: 2).

Out of 113 fractures that occurred in the mandible 39 (34.5\%) were multiple and 74 (65.5\%) were isolated fractures, 
Table 2: Frequency and percentages of pediatric fractures

\begin{tabular}{|c|c|c|}
\hline Fracture Type & Frequency & Percentage \\
\hline Mandible Fracture & 113 & $71.9 \%$ \\
\hline Maxillary Fracture & 13 & $8.2 \%$ \\
\hline $\begin{array}{c}\text { Dentoalveolar } \\
\text { Fracture }\end{array}$ & 18 & $11.4 \%$ \\
\hline $\begin{array}{c}\text { Zygoma Fracture } \\
\text { Frontal bone }\end{array}$ & 1 & $5.1 \%$ \\
\hline $\begin{array}{c}\text { NOE Fracture } \\
\text { Mid palatal split }\end{array}$ & 1 & $0.7 \%$ \\
\hline $\begin{array}{c}\text { Orbital floor } \\
\text { fracture }\end{array}$ & 1 & $0.7 \%$ \\
\hline Total & 157 & $0.7 \%$ \\
\hline
\end{tabular}

Table 3: Pattern of pediatric mandibular fractures

\begin{tabular}{|c|c|c|c|}
\hline No. & Site of fracture & Frequency & Percentage \\
\hline 1. & Symphysis fracture & 11 & $9.7 \%$ \\
\hline 2. & Parasymphysis fracture & 42 & $37.1 \%$ \\
\hline 3. & Body fracture & 9 & $8.0 \%$ \\
\hline 4. & Angle fracture & 2 & $1.8 \%$ \\
\hline 5. & Ramus fracture & 1 & $0.8 \%$ \\
\hline 6. & Unilateral condylar fracture & 6 & $5.3 \%$ \\
\hline 7. & Bilateral condylar fracture & 3 & $2.6 \%$ \\
\hline 8. & $\begin{array}{l}\text { Symphysis and bilateral condylar } \\
\text { fracture }\end{array}$ & 7 & $6.3 \%$ \\
\hline 9. & $\begin{array}{l}\text { Parasymphysis and unilateral } \\
\text { condylar fracture }\end{array}$ & 7 & $6.3 \%$ \\
\hline 10. & Parasymphysis and angle fracture & 9 & $8.0 \%$ \\
\hline 11. & Symphysis and angle fracture & 2 & $1.8 \%$ \\
\hline 12. & Bilateral body fracture & 2 & $1.8 \%$ \\
\hline 13. & Parasymphysis and body fracture & 4 & $3.0 \%$ \\
\hline 14. & $\begin{array}{l}\text { Bilateral parasymphysis and } \\
\text { unilateral condylar fracture }\end{array}$ & 1 & $0.8 \%$ \\
\hline 15. & Parasymphysis and ramus fracture & 1 & $0.8 \%$ \\
\hline 16. & $\begin{array}{l}\text { Symphysis and unilateral condylar } \\
\text { fracture }\end{array}$ & 2 & $1.8 \%$ \\
\hline 17. & $\begin{array}{l}\text { Parasymphysis and bilateral } \\
\text { condylar fracture }\end{array}$ & 2 & $1.8 \%$ \\
\hline 18. & $\begin{array}{l}\text { Angle, parasymphysis and } \\
\text { unilateral condylar fracture }\end{array}$ & 1 & $0.8 \%$ \\
\hline 19. & Bilateral parasymphysis fracture & 1 & $0.8 \%$ \\
\hline & Total & 113 & $100 \%$ \\
\hline
\end{tabular}

maximum belonging to the parasymphysis region $42(37.1 \%)$ (Table: 3 ).

Of the 44 other fractures, the most common were dentoalveolar fractures $18(11.4 \%)$ followed by maxillary fractures $13(8.2 \%)$, zygoma fractures $8(5.1 \%)$, mid palatal split $2(1.27 \%)$ whereas frontal bone, NOE, and orbital floor fractures showed 1 fracture each (Table:4).

With regard to treatment methods, $43(31.9 \%)$ of all the patients were managed by open reduction and internal fixation Table 4: Pattern of pediatric upper and middle third of face fractures

\begin{tabular}{|c|c|c|c|}
\hline No. & Type of fracture & Frequency & Percentage \\
\hline \multirow{3}{*}{1.} & $\begin{array}{c}\text { Maxillary Fractures } \\
\text { Lefort I fracture }\end{array}$ & 6 & $46.1 \%$ \\
\hline & Lefort II fracture & 7 & $53.9 \%$ \\
\hline & Total & 13 & $100 \%$ \\
\hline \multirow{4}{*}{2.} & $\begin{array}{l}\text { Dentoalveolar Fractures } \\
\text { Upper dentoalveolar fracture }\end{array}$ & 11 & $61.1 \%$ \\
\hline & Lower dentoalveolar fracture & 3 & $16.7 \%$ \\
\hline & $\begin{array}{r}\begin{array}{r}\text { Upper \& Lower dentoalveolar } \\
\text { fracture }\end{array}\end{array}$ & 4 & $22.2 \%$ \\
\hline & $\begin{array}{ll}\text { Total } \\
\end{array}$ & 18 & $100 \%$ \\
\hline \multirow{2}{*}{3.} & Zygoma Fractures & 8 & $100 \%$ \\
\hline & Total & 8 & $100 \%$ \\
\hline \multirow[t]{2}{*}{4.} & $\begin{array}{c}\begin{array}{c}\text { Frontal Bone Fracture } \\
\text { Fracture }\end{array} \\
\end{array}$ & 1 & $100 \%$ \\
\hline & Total & 1 & $100 \%$ \\
\hline \multirow[t]{2}{*}{5.} & $\begin{array}{rr}\text { NOE Fracture } & \\
& \text { Fracture } \\
\end{array}$ & 1 & $100 \%$ \\
\hline & Total & 1 & $100 \%$ \\
\hline \multirow[t]{2}{*}{6.} & $\begin{array}{l}\text { Mid Palatal Split } \\
\text { Fracture }\end{array}$ & 2 & $100 \%$ \\
\hline & Total & 2 & $100 \%$ \\
\hline \multirow[t]{2}{*}{7.} & $\begin{array}{l}\text { Orbital Floor Fracture } \\
\text { Fracture }\end{array}$ & 1 & $100 \%$ \\
\hline & Total & 1 & $100 \%$ \\
\hline
\end{tabular}

Table 5: Treatment modalities used among pediatric patients

\begin{tabular}{|c|c|c|}
\hline $\begin{array}{c}\text { Treatment } \\
\text { modalities }\end{array}$ & Frequency & Percentage \\
\hline ORIF & 43 & $31.9 \%$ \\
\hline MMF with arch bar & 7 & $5.2 \%$ \\
\hline MMF with eyelets & 35 & $25.9 \%$ \\
\hline MMF with ORIF & 36 & $26.7 \%$ \\
\hline Arch bar & 3 & $2.2 \%$ \\
\hline Observation & 10 & $7.4 \%$ \\
\hline $\begin{array}{c}\text { ORIF with } \\
\text { Titanium mesh }\end{array}$ & 1 & $0.7 \%$ \\
\hline Total & 135 & $100 \%$ \\
\hline
\end{tabular}


(ORIF) alone and $36(26.7 \%)$ patients were treated with ORIF plus MMF whereas only $1(0.7 \%)$ patient was treated by ORIF with titanium mesh. Closed reduction by means of MMF with eyelets was done in 35 (25.9\%) and MMF with arch bar was done in $7(5.2 \%)$ patients. $10(7.4 \%)$ patients were kept on observation and arch bar alone was used in 3 (2.2\%) patients only (Table:5).

The concomitant injuries were observed in $31(22.9 \%)$ patients. Of these, neuro-cranial injuries were the most common and observed in 19 (61.3\%) patients. Other associated injuries were shown in (Table:6).

Lastly in this study complications were observed in 16 (11.9\%) patients only and among these 16 patients, limited

Table 6: Associated injuries among pediatric patients

\begin{tabular}{|c|c|c|}
\hline Associated injuries & Frequency & Percentage \\
\hline $\begin{array}{c}\text { Neurocranial } \\
\text { injuries }\end{array}$ & 19 & $61.3 \%$ \\
\hline Thoracic injuries & 3 & $9.7 \%$ \\
\hline Abdominal injuries & 1 & $3.2 \%$ \\
\hline Upper limb injuries & 5 & $16.1 \%$ \\
\hline Lower limb injuries & 3 & $9.7 \%$ \\
\hline Total & 31 & $100 \%$ \\
\hline
\end{tabular}

Table 7: Complications among pediatric fractures

\begin{tabular}{|c|c|c|}
\hline Complications & Frequency & Percentage \\
\hline Non union & 2 & $12.5 \%$ \\
\hline $\begin{array}{c}\text { Post-op wound } \\
\text { infection }\end{array}$ & 5 & $31.2 \%$ \\
\hline Malocclusion & 1 & $6.3 \%$ \\
\hline $\begin{array}{c}\text { Limited mouth } \\
\text { opening }\end{array}$ & 16 & $50 \%$ \\
\hline Total & $100 \%$ \\
\hline
\end{tabular}

mouth opening was responsible for maximum complications $8(50 \%)$ patients. Other complications were shown in (Table:7).

\section{DISCUSSION}

Pediatric maxillofacial trauma under 5 years is infrequent as majority of children live under close supervision of parents and adults with uncompromising check on their physical activities thus restraining them from fractures and injuries.10,11 The first peak in frequency of pediatric facial fractures is reported to occur at 5-6 years associated with school attendance. The second peak noted at 10-12 years is affiliated with expanded outdoor activity and engagement in sports during puberty and juvenescence..$^{9,12}$

In this current study the mean age of the pediatric patients who suffered from maxillofacial trauma was $6.51+2.63$ years. The minimum age was 2 years whereas the maximum age noted was 11 years. This is in agreement with many other studies like Massenburg et $\mathrm{al}^{13}$ and Allred et a ${ }^{14}$ who showed that majority of pediatric maxillofacial trauma was noted at the mean age of 6.23 years and 5.82 years respectively. ${ }^{13,14}$

Pediatric maxillofacial injuries were found to occur in a large number of boys 91 (67.4\%) as compared to girls 44 $(32.6 \%)$ with a male to female ratio of $1.8: 1$. The prevalence of males is accredited to the reality that their outdoor activity is more extreme and precarious than that of females. ${ }^{1,4,13}$ The lesser number of girls in this study may be due to a largely conservative socio-cultural environment in the Pakistan where girls are protected and there are little opportunities for female children to indulge in sports and physical activities which may put them at a risk of injury. ${ }^{1}$ It is well established in the case of maxillofacial fractures that the male patients outnumber their female counter parts in all age groups worldwide. , $7,11,15^{2}$

The main source for the pediatric maxillofacial trauma in this study was due to fall with a very large frequency of $83(61.5 \%)$. This result of the present is in accordance with the results of Joachim et $\mathrm{al}^{9}$ who also noticed that fall (48\%) is the main reason of these fractures. ${ }^{9}$ As the young child grows they learns to walk and run which results in more falls on the ground or from height. ${ }^{1,9}$ However Yunus et al ${ }^{16}$ mentioned that road traffic accident is the major reason of fracture in the children. ${ }^{16}$ Only $40(29.6 \%)$ of the trauma in our study was due to RTA. Falls and RTA were followed by sports injury in $5.9 \%$, assault in $1.5 \%$ gunshot injury in $0.7 \%$ and animal related injury in $0.7 \%$.

Among 135 pediatric maxillofacial trauma patients there were 157 different types of fracture combinations. Among these 157 fractures the mandible was the main fractured site in the current study $113(71.9 \%)$. This was in accordance with the studies conducted by Teshome et $\mathrm{al}^{6}{ }^{6}$, Lim et $\mathrm{al}^{12}$ and Yunus et al. ${ }^{16}$ In contrary fractures of the mid face were common in a Chinese study conducted by Qing-Bin et al. ${ }^{1}$ The low occurrence of recognition of fractures of the middle third of the face in this study is possibly due to the improper referral of the patients at tertiary care centers. ${ }^{4}$ The present study depicted that among mandible fractures, parasymphysis was most commonly affected $37.1 \%$ fractures in pediatric population. The weakness of mandible is because of increase tooth to bone ratio (existence of permanent tooth buds), thinness of bone and curvature of the mandible., ${ }^{5,18}$ This 
result is in disagreement with the results of Joachim et al ${ }^{9}$ who described that condyle was the main site of fracture. ${ }^{9}$ Majority of the fractures in this study were treated by open reduction and internal fixation (ORIF) technique. The criteria for ORIF were displacement of the fractures on the horizontal and vertical planes of x-rays. In majority of these cases intraoral approach was used unless existing laceration was present which was used as an incision. 43 (31.9\%) patients were treated with ORIF alone, $36(26.7 \%)$ were treated with ORIF with MMF and $1(0.7 \%)$ patient was treated with ORIF with titanium mesh. Closed reduction with MMF with eyelets was done in 35 (25.9\%) patients and MMF with arch bar was done in 7 (5.2\%) patients, were the fractures were only minimally displaced. Arch bar alone was used in 3 $(2.2 \%)$ patients and finally $10(7.4 \%)$ patients were kept on observation, where the fractures were not displaced. The plates were removed after 3 months and patients were followed up on regular intervals for 6 months. ${ }^{4}$ During these follow ups radiographs taken manifested satisfactory osteogenic prospective of the involved bone.,11 To surpass the second surgical procedure bioresorbable plates are often used these days but as this study was conducted in a government hospital and majority of the patients are from poor background who could not afford expensive bioresorbale plates.

Thirty-one $(22.9 \%)$ patients from a total of $135(100 \%)$ patients in this study were documented to have associated injuries. Associated injuries with pediatric maxillofacial trauma reported in the literature vary widely in the range of $10 \%-78 \%$ depending on the particular type of facial fractures. ${ }^{3,4,13,16}$ The most common associated injuries in pediatric maxillofacial trauma were reported to be neurocranial injuries. ${ }^{1,4,16}$ In our study also a majority of associated injuries were head injuries 19 (61.3\%). Whereas upper and lower limb injuries accounted for $8(25.8 \%)$ of total associated injuries.

There were 16 (11.9\%) complications observed in this study within 6 months follow up time, which is lower than the results founded by Joachim et al.9 In our study 8 (50\%) patients presented with limited mouth opening in the postoperative follow up period and majority of these patients have condylar fractures. Mouth opening exercises were done in the follow up visits to prevent ankylosis. Fortunately, none of these patients developed true postoperative ankylosis. Further 5 (31.2\%) patients mainly those who underwent ORIF using bone plates presented with post operative wound infection and non union was noted in $2(12.5 \%)$ patients which was managed conservatively by local irrigation, debridement, and antibiotics. Finally, malocclusion was noted in $1(6.3 \%)$ patient only which was corrected by guiding elastics.

\section{CONCLUSION \& RECOMMENDATIONS}

The results of this study confirmed the pediatric male patient's predominance. Fracture of the mandible was the most numerous cause of pediatric maxillofacial trauma. Fall accounts for the most of fractures in younger age group, road traffic accident being the second most as the child increases in age. Majority of maxillofacial fractures were managed by ORIF. Management of injured patients should also be aimed at reducing the incidences of maxillofacial injuries in pediatric population by using preventive and interventional programs. There is a need at a national level for a public, parent and teacher education program on childcare and safety. Injuries on other parts of the body may occur in patients with maxillofacial trauma and conversely maxillofacial trauma may coexist with other body part injuries in excessive percentage of cases. This inter-relationship makes it compulsory for the oral \& maxillofacial surgeon to be part of a multidisciplinary trauma team.

\section{LIMITATION OF THE STUDY}

Some of patients medical records were incomplete and were excluded from the study.

Therefore, a larger sample size prospective study should be done to make a conclusive finding on the epidemiology of maxillofacial trauma in Pakistan.

\section{CONFLICT OF INTEREST}

None declared

\section{REFERENCES}

1.Qing-Bin Z, Zhao-Qiang Z, Dan C, Yan Z. Epidemiology of maxillofacial injury in children under 15 years of age in southern China. Oral Surg, Oral Medi, Oral Pathol Oral Radiol. 2013;115:43641.

https://doi.org/10.1016/j.oooo.2012.04.026

2. Zimmermann CE, Troulis MJ, Kaban LB. Pediatric facial fractures: recent advances in prevention, diagnosis and management. Int J Oral Maxillofac Surg. 2005;34:823-33.

https://doi.org/10.1016/j.ijom.2005.06.015

3. Khan MA, Ishfaq M, Akhtar M, Rana SA, Kashif M. Frequency of paediatric facial trauma in a tertiary care dental hospital. Int Surg J. 2017;5:310-4.

https://doi.org/10.18203/2349-2902.isj20175917

4. Kambalimath HV, Agarwal SM, Kambalimath DH, Singh M, Jain N, Michael P. Maxillofacial injuries in children: a 10-year retrospective study. J Maxillofac Oral Surg. 2013;12:140-44.

https://doi.org/10.1007/s12663-012-0402-6 
5. Pandey RK, Mishra A. The incidence of facial injuries in children in Indian population: A retrospective study. J Oral Biol Craniofac Res. 2018;8:82-5.

https://doi.org/10.1016/j.jobcr.2017.09.006

6. Teshome A, Andualem G, Tsegie R, Seifu S. Two years retrospective study of maxillofacial trauma at a tertiary center in North West Ethiopia. BMC research notes. $2017 ; 10: 373$.

https://doi.org/10.1186/s13104-017-2670-1

7. Gupta A, Babu AK, Bansal P, Sharma R, Sharma SD. Changing trends in maxillofacial trauma: A 15 years retrospective study in the Southern Part of Haryana, India. Indian J Dent Res. 2018;29:190. https://doi.org/10.4103/ijdr.IJDR_202_17

8. Haq ME, Khan AS. A retrospective study of causes, management, and complications of pediatric facial fractures. Europ J Denti. 2018;12:247.

https://doi.org/10.4103/ejd.ejd_370_17

9. Joachim M, Tuizer M, Araidy S, Abu El-Naaj I. Pediatric maxillofacial trauma: Epidemiologic study between the years 2012 and 2015 in an Israeli medical center. Dent Traumatol. 2018;34: 221-28.

https://doi.org/10.1111/edt.12406

10. Ghosh R, Gopalkrishnan K, Anand J. Pediatric facial fractures: a 10-year study. Journal Maxillofac Oral Surg. 2018;17:158-63. https://doi.org/10.1007/s12663-016-0965-8

11. Chandra SR, Zemplenyi KS. Issues in Pediatric CraniofacialTrauma. Facial Plastic Surg Clin 2017;25:581-91. https://doi.org/10.1016/j.fsc.2017.06.009

12. Lim CA, Singh YK, Portnof JE, Blumberg SM. Pediatric maxillofacial trauma: A review of 156 patients. J Oral Maxillofac
Surg. 2016;74:1420-e1.

https://doi.org/10.1016/j.joms.2016.03.001

13. Massenburg BB, Sanati-Mehrizy P, Taub PJ. Surgical treatment of pediatric craniofacial fractures: A national perspective. J Craniofac Surg. 2015;26:2375-80

https://doi.org/10.1097/SCS.0000000000002146

14. Allred LJ, Crantford JC, Reynolds MF, David LR. Analysis of pediatric maxillofacial fractures requiring operative treatment: characteristics, management, and outcomes. J Craniofac Surg. 2015;26:2368-74.

https://doi.org/10.1097/SCS.0000000000002087

15. Andrade NN, Choradia S. An institutional experience in the management of pediatric mandibular fractures: a study of 74 cases. J Cranio-Maxillofac Surg. 2015;43:995-99.

https://doi.org/10.1016/j.jcms.2015.03.020

16. Yunus SS, Ngeow WC, Ramli R. Pediatric craniomaxillofacial injuries after road traffic crashes: characteristics of injuries and protective equipment use. Am J Emerg Med. 2015;33:1253-57. https://doi.org/10.1016/j.ajem.2015.05.009

17. Ferreira PC, Barbosa J, Braga JM, Rodrigues A, Silva ÁC, Amarante JM. Pediatric facial fractures: a review of 2071 fractures. Annals Plastic Surg. 2016;77:54-60.

https://doi.org/10.1097/SAP.0000000000000346

18.Daniel OO, Ngutor V, Idemudia AB, Adetokunbo AR, Cornelius IA, Akinwale EA. Pediatric maxillofacial injuries at a Nigerian teaching hospital: A three-year review. Nigerian J Clini Prac. 2013;16:149-54. https://doi.org/10.4103/1119-3077.110126 